\title{
IN VIVO ANTIOXIDANT ACTIVITY OF LIMNOPHILA HETEROPHYLLA AND MICHELIA CHAMPACA
}

\author{
RAJA S., RAVINDRANADH K. \\ GITAM Institute of Pharmacy, GITAM University, Visakhapatnam Andhra Pradesh, India 530045 \\ Email: sraja61@gmail.com
}

Received: 14 Aug 2017 Revised and Accepted: 02 Nov 2017

\begin{abstract}
Objective: The present study was aimed at investigating the in-vivo antioxidant activity of the methanol extracts of Limnophila heterophylla and Michelia champaca leaves.

Methods: Methanol extract of both plants were administered to rats separately at three different doses of 125,250 and 500 mg/kg for $21 \mathrm{~d}$ to evaluate oxidative stress parameters such as ferric reducing ability of plasma (FRAP), thiobarbituric acid reactive substance (TBARS) and reduced glutathione (GSH) and to evaluate antioxidant enzyme levels of catalase (CAT) and superoxide dismutase (SOD).

Results: The methanol extracts of both the plants significantly $(\mathrm{p}<0.05)$ elevated the ferric reducing ability of plasma (FRAP) on days 7,14 and 21 of treatment. Significant $(\mathrm{p}<0.05)$ decrease of thiobarbituric acid reactive substance (TBARS) levels along with an increase in the superoxide dismutase (SOD) enzyme level in the liver and kidney at three different doses both the plants was observed. Treatment at a dose of $500 \mathrm{mg} / \mathrm{kg}$ b. w of both plants caused a significant increase only in the level of CAT in the liver and kidney. However, there was no significant effect of a thiobarbituric acid reactive substance (TBARS), superoxide dismutase (SOD) and catalase (CAT) in the heart and reduced glutathione (GSH) level in liver, heart and kidney at three different doses both the plants.
\end{abstract}

Conclusion: These outcomes recommend that the leaves of Limnophila heterophylla and Michelia champaca have a potent antioxidant activity which may be responsible for some of its reported pharmacological actions.

Keywords: Limnophila heterophylla, Michelia champaca, FRAP, Catalase, TBARS, GSH

(C) 2017 The Authors. Published by Innovare Academic Sciences Pvt Ltd. This is an open-access article under the CC BY license (http://creativecommons.org/licenses/by/4.0/ DOI: http://dx.doi.org/10.22159/ijpps.2017v9i12.22013

\section{INTRODUCTION}

In the development of diseases, free radicals have emerged because the major entity inflicting harm to cells. These cytotoxic metabolites are generated by aerobic metabolism within the cell that successively considerably will increase pathological conditions, resulting in free radical mediate denaturation of protein, enzymatic deactivation, base hydroxylation of nucleic acids, cross-linking or strand cutting, mutation or maybe death [1]. However, the physiological system has a series of defense mechanism including antioxidant enzymes-superoxide dismutase (SOD), catalase (CAT), glutathione peroxidase (GPX), Thiobarbituric acid reactive substances (TBARS), reduced glutathione (GSH), and other free radical scavengers, $\beta$-carotene, vitamin $\mathrm{C}$, vitamin $\mathrm{E}, \alpha$-lipoic acid, curcumin, rutin, BHT and glutathione to protect the cell against cytotoxic ROS (reactive oxygen species) [2]. The antioxidants in a biological system can be either enzymatic or non-enzymatic. The enzymatic antioxidants include catalase (CAT), superoxide dismutase (SOD), and glutathione which catalyse neutralization of many types of free radicals [3], while the nonenzymatic antioxidants include vitamin $\mathrm{C}$, selenium, vitamin $\mathrm{E}$, carotenoids, and polyphenols. The enzymatic antioxidants catalyse neutralization of many types of free radicals [3]. However, when the balance between the oxygen species and antioxidants is altered, a state of oxidative stress results, possibly leading to everlasting cellular damage. There is evidence that antioxidants may be useful in preventing the deleterious consequences of oxidative stress, and there is an increasing interest in the protective biochemical function of natural antioxidants contained in vegetables, fruits and medicinal herbs [4]. Generally, plants, herbs, and spice, rich in phenolic compounds like flavonoids, have been demonstrated to have anti-inflammatory, antiallergenic, antiviral, antiaging and anticarcinogenic activities which can be attributed to their antioxidant properties [5]. In this respect, flavonoids and polyphenolic compounds have received the greatest attention [6-8].
Limnophila heterophylla is an aquatic herb, mainly submerged, but with shoots that often emerge above the water surface, rooting at nodes. The plant finds lot of applications in the traditional system of medicine to treat wounds [9]. Different parts of Limnophila heterophylla possess varied pharmacological activities like COX inhibitor [10], antimicrobial [11] and wound healing [12]. The plant encloses terpene, flavanoids, terpinoids and oils [13]. Michelia, known by the scientific name Michelia champaca, is a very tall tree that grows up to $30 \mathrm{~m}$ tall. Michelia champaca is used ethnomedicinally for the handling of astringent, constipation, dyspepsia, dysmenorrhea, fever, febrifuge, nausea, stomachic, skin disease, tonic, ulcers and wounds [14]. Earlier pharmacological reports of Michelia champaca had demonstrated its cytotoxic activity [15], anti-inflammatory [16], antihyperglycemic [17], leishmanicidal [18], antibacterial [19], wound healing [20], diuretic [21], antiulcer [22], antifertility [23], antihelmintic [24] and cardioprotective [25] activities. Several phytoconstituents like alkaloids, flavonoids, triterpenoids, saponins, tannins, sterols and steroids have been isolated from different parts Michelia champaca.

Based on these reports, this study was designed to investigate the in vivo antioxidant activity of methanol extracts of leaves of Limnophila heterophylla and Michelia champaca.

\section{MATERIALS AND METHODS}

\section{Plant materials}

The plants were collected from Tirupati (Andhra Pradesh), India and further, plants were distinguished, affirmed and validated by Dr. Madavchetty, Professor, Botany office, Sri Venkateswara University, Tirupati. A voucher specimen of these plants (Limnophila heterophylla-GIP006/2013-2014 and Michelia champacaGIP005/2013-2014) have been kept in the GITAM Institute of Pharmacy, GITAM University, Visakhapatnam, Andhra Pradesh, India. 


\section{Chemicals and reagents}

All chemicals used in the study were of analytical grade and they were procured from Coastal Enterprises Pvt. Ltd., Visakhapatnam, Andhra Pradesh and India.

\section{Extraction}

Leaves of Limnophila heterophylla and Michelia champaca were dried under shade and then powdered with a mechanical grinder to obtain a coarse powder. The powder was passed through 40 mesh sieve and extracted with methanol separately in Soxhlet apparatus at $60{ }^{\circ} \mathrm{C}$. The solvent was completely removed by rotary vacuum evaporator and concentrated. The extracts were freeze-dried and stored in a vacuum desiccator for further in vivo antioxidant studies.

\section{Test animals and groups}

Wistar albino rats (200-250 gm) of either sex were maintained under standard environmental conditions and had free access to feed and water ad libitum. Experiments on animals were performed based on animal ethics guidelines of Institutional Animal Ethics Committee (IAEC). Rats were divided into seven groups of six animals each. Group, I served as control and was given the vehicle alone (normal saline). Group II, III and IV received methanol extract of Limnophila heterophylla orally at 125, 250 and $500 \mathrm{mg} / \mathrm{kg}$ body weight, individually. Group V, VI and VII received methanol extract of Michelia champaca orally at 125, 250 and $500 \mathrm{mg} / \mathrm{kg}$ body weight, separately. The treatments were given for $21 \mathrm{~d}$ and all the animals were sacrificed by decapitation on $22^{\text {nd }}$ day of the experiment. Blood was collected through the direct cardiac puncture and it was used for in vivo antioxidant activity. The heart, liver and kidney were removed, washed in cold saline and stored in liquid nitrogen for further biochemical studies. This in vivo antioxidant activity was analyzed by the method described by Rajlakshmi et al. [26].

\section{Serum preparation}

Blood was allowed to clot for $30 \mathrm{~min}$, then centrifuged at $2500 \mathrm{rpm}$ for $15 \mathrm{~min}$ and serum was harvested. The serum was prepared using standard method as described by Yesufu et al., [27] and it was used for the estimation of superoxide dismutase (SOD), catalase (CAT) and malonyldialdehyde (MDA).

\section{Preparation of rat heart, liver and kidney homogenate}

Tissue homogenate was prepared in a ratio of $1 \mathrm{gm}$ of wet tissue to 10 times (w/v) $0.05 \mathrm{~mol} / \mathrm{l}$ ice-cold phosphate buffer ( $\mathrm{pH} 7.4$ ) and homogenised using a homogenizer (Tissue homogeniser). A $0.2 \mathrm{ml}$ sample of homogenate was used for assessment of thiobarbituric acid reactive substance (TBARS). The leftover part of the homogenate was separated into two parts. One part was mixed with $10 \%$ trichloroacetic acid (1:1), centrifuged at $5000 \mathrm{~g}\left(4^{\circ} \mathrm{C}\right.$, for 10 $\mathrm{min}$ ) and the supernatant was used for reduced glutathione (GSH) estimation. The second part of the homogenate was centrifuged at $15000 \mathrm{~g}$ at $4{ }^{\circ} \mathrm{C}$ for $60 \mathrm{~min}$ and the supernatant was used for superoxide dismutase (SOD) and catalase (CAT) estimation.

\section{Ferric reducing ability of plasma (FRAP) assay}

Total plasma antioxidant capacity was measured according to the ferric reducing ability of plasma (FRAP) method [28]. The blood samples were collected from the rat retro-orbital venous plexus into heparinised glass tubes at 0, 714 and $21 \mathrm{~d}$ of treatment. Briefly, $3 \mathrm{ml}$ of freshly prepared and warm $\left(37^{\circ} \mathrm{C}\right)$ FRAP reagent $(1 \mathrm{ml}$ of 10 mmol/l TPTZ [2,4,6 tripyridyl-s-triazine] solution in $40 \mathrm{mmol} / \mathrm{l} \mathrm{HCl}$, $1 \mathrm{ml} 20 \mathrm{mmol} / \mathrm{F} \mathrm{FeCl}_{2} .6 \mathrm{H}_{2} \mathrm{O}, 10 \mathrm{ml}$ of $0.3 \mathrm{mmol} / \mathrm{l}$ acetate buffer $[\mathrm{pH}$ 3.6]) was mixed with $0.375 \mathrm{ml}$ distilled water and $0.025 \mathrm{ml}$ of test samples. The absorbance of developed colour in the organic layer was measured at $593 \mathrm{~nm}$. The temperature was maintained at $37^{\circ} \mathrm{C}$. The readings at $180 \mathrm{sec}$ were selected for the calculation of FRAP values. Ferrous sulphate $\left(\mathrm{FeSO}_{4} .7 \mathrm{H}_{2} \mathrm{O}\right)$ was used as a standard for calibration and the data expressed as $\mathrm{nmol} \mathrm{Fe} \mathrm{Fe}^{2+} / \mathrm{l}$.

\section{Superoxide dismutase assay}

Superoxide dismutase (SOD) activity was analysed by the method described by Rai et al., [29]. Assay mixture contain $0.1 \mathrm{ml}$ of supernatant/serum, $1.2 \mathrm{ml}$ of sodium pyrophosphate buffer $(\mathrm{pH} 8.3$;
$0.052 \mathrm{M}), 0.1 \mathrm{ml}$ of phenazine methosulfate (186 mmol), $0.3 \mathrm{ml}$ of nitroblue tetrazolium ( $300 \mathrm{mmol})$, and $0.2 \mathrm{ml}$ of NADH $(750 \mathrm{mmol})$. The reaction was started by the addition of $\mathrm{NADH}$. After Incubation at $30^{\circ} \mathrm{C}$ for $90 \mathrm{~s}$, the reaction was stopped by the addition of $0.1 \mathrm{ml}$ of glacial acetic acid. The reaction mixture was stirred vigorously with four $\mathrm{ml}$ of n-butanol. Color intensity of the chromogen in the butanol was measured spectrophotometrically at $560 \mathrm{~nm}$ and the concentration of superoxide dismutase (SOD) was expressed as units/mg of protein.

\section{Catalase assay}

Catalase activity (CAT) was measured by the method of Aebi [30]. A 0.1 $\mathrm{ml}$ of supernatant/serum was added to a cuvette containing $1.9 \mathrm{ml}$ of 50 mmol phosphate buffer $(\mathrm{pH} 7.0)$. The reaction was started by the addition of $1.0 \mathrm{ml}$ of freshly prepared $30 \mathrm{mmol} \mathrm{H}_{2} \mathrm{O}_{2}$. The rate of the decomposition of $\mathrm{H}_{2} \mathrm{O}_{2}$ was measured spectrophotometrically at 240 $\mathrm{nm}$. The activity of catalase (CAT) was expressed as units/mg of protein.

\section{Estimation of thiobarbituric acid reactive substance (TBARS)}

Lipid peroxidation (LPO) was measured by the method of Liu et al., [31]. Acetic acid $1.5 \mathrm{ml}$ (20\%; pH 3.5), 1.5 of TBA ( $0.8 \%)$, and $0.2 \mathrm{ml}$ of sodium dodecyl sulfate $(8.1 \%)$ was added to $0.1 \mathrm{ml}$ of supernatant/serum and heated at $100{ }^{\circ} \mathrm{C}$ for $60 \mathrm{~min}$. The mixture was cooled to room temperature. To this, $5 \mathrm{ml}$ of n-butanol: pyridine mixture and $1 \mathrm{ml}$ of distilled water were added and vortexed vigorously. After centrifugation at $1200 \mathrm{~g}$ for $10 \mathrm{~min}$, the organic layer was separated and the absorbance was measured at $532 \mathrm{~nm}$ using a spectrophotometer. Malonyldialdehyde (MDA) was an end product of LPO, which reacts with TBA to form pink chromogen-TBA reactive substance. It was calculated using a molar extinction coefficient of 1.56 $\mathrm{X} 105 \mathrm{M}-1 \mathrm{~cm}-1$ and it was expressed as nM/g wet wt.

\section{Estimation of reduced glutathione (GSH)}

Glutathione was measured according to the method of Ellman [32]. An equal quantity of homogenate was mixed with $10 \%$ trichloroacetic acid and it was centrifuged to separate the proteins. To $0.01 \mathrm{ml}$ of this supernatant, $2 \mathrm{ml}$ of phosphate buffer ( $\mathrm{pH} 8.4$ ), 0.5 $\mathrm{ml}$ of 5'5-dithio, bis (2-nitrobenzoic acid) and $0.4 \mathrm{ml}$ double distilled water was added. The mixture was vortexed and the absorbance was read at $412 \mathrm{~nm}$ within $15 \mathrm{~min}$. The concentration of reduced glutathione was expressed as $\mu \mathrm{g} / \mathrm{g}$ tissue.

\section{Statistical analysis}

All experimental data were expressed as mean \pm standard error of the mean (SEM). This Statistical analysis was carried out using one-way analysis of variance (ANOVA) followed by Dunnet-t-test with the SPSS statistical software for comparison to the control group. $\mathrm{p}<0.05$ was considered as statistically signi ficant.

\section{RESULTS}

\section{Serum enzymatic levels of MDA, SOD and CAT}

The results of the serum enzymatic levels of malonyldialdehyde (MDA), superoxide dismutase (SOD) and catalase (CAT) of individual methanol extract of Limnophila heterophylla and Michelia champaca were mentioned in table 1 . At a dose of $250 \mathrm{mg} / \mathrm{kg}$ both the extracts exhibited moderate significant $(\mathrm{p}<0.05, \mathrm{p}<0.01$ and $\mathrm{p}<0.001)$ decrease in the serum level of malonyldialdehyde (MDA) in the test animals (group II to VII) when compared to control. However, only the higher dose $(500 \mathrm{mg} / \mathrm{kg})$ of both the plant methanol extracts produced a significant $(\mathrm{p}<0.001)$ decrease in the serum levels of malonyldialdehyde (MDA) when compared with control. The extracts of treated rats also evoked a dose-related significant $(p<0.05, p<0.01$ and $\mathrm{p}<0.001$ ) increase in the serum levels of catalase (CAT) and superoxide dismutase (SOD) when compared to control. Methanol extracts of both the plants at a dose of $250 \mathrm{mg} / \mathrm{kg}$ showed moderate significant $(p<0.01)$ elevation in serum levels of catalase (CAT) and superoxide dismutase (SOD). However, only the higher dose (500 $\mathrm{mg} / \mathrm{kg}$ ) of both the plant methanol extracts caused a significant $(p<0.001)$ increase in the serum levels of catalase (CAT) and superoxide dismutase (SOD) when compared with control. However, there was mild significant $(\mathrm{p}<0.05)$ changes of malonyldialdehyde (MDA), superoxide dismutase (SOD) and catalase (CAT) levels were observed in $125 \mathrm{mg} / \mathrm{kg}$ of both the plant methanol extracts. 
Table 1: Serum enzymatic levels of MDA, SOD and CAT

\begin{tabular}{llll}
\hline Group & MDA (nM of TBARS mg-1 of protein) & SOD U/mg protein & CAT U/mg protein \\
\hline Group-I & $0.46 \pm 0.32$ & $46.26 \pm 1.28$ & $26.22 \pm 0.01$ \\
Group-II & $0.39 \pm 0.01^{*}$ & $48.14 \pm 2.62^{*}$ & $26.82 \pm 0.18^{*}$ \\
Group-III & $0.33 \pm 0.12^{* *}$ & $53.6 \pm 1.37^{* *}$ & $28.44 \pm 1.12^{* *}$ \\
Group-IV & $0.29 \pm 1.32^{* * *}$ & $54.8 \pm 1.09^{* * *}$ & $40.06 \pm 1.87^{* * *}$ \\
Group-V & $0.44 \pm 0.02^{*}$ & $45.23 \pm 1.23^{*}$ & $22.12 \pm 0.08^{*}$ \\
Group-VI & $0.36 \pm 0.32^{* *}$ & $49.7 \pm 1.08^{* *}$ & $26.32 \pm 1.23^{* *}$ \\
Group-VII & $0.32 \pm 0.42^{* * *}$ & $51.7 \pm 1.22^{* * *}$ & $37.25 \pm 1.82^{* * *}$ \\
\hline
\end{tabular}

$\left[\mathrm{p}<0.05^{*}, \mathrm{p}<0.01^{* *}\right.$ and $\left.\mathrm{p}<0.001^{* * *}\right]$

\section{Ferric reducing ability of plasma (FRAP) assay}

The ferric reducing ability of plasma (FRAP) level of rats after administration of methanol extracts of Limnophila heterophylla and Michelia champaca over a period of $21 \mathrm{~d}$ was presented in fig. 1. In the control group, there was no significant change in ferric reducing ability of plasma (FRAP) value on days $7\left(870 \mathrm{nM} \mathrm{Fe}^{2+} / \mathrm{l}\right)$ $14\left(869 \mathrm{nM} \mathrm{Fe}^{2+} / \mathrm{l}\right)$ and $21\left(868 \mathrm{nM} \mathrm{Fe}^{2+} / \mathrm{l}\right)$ compared with day 0 $\left(864 \mathrm{nM} \mathrm{Fe}^{2+} / \mathrm{l}\right)$. But, in group II, III and IV on days $7(947,1088$ and $1101 \mathrm{nM} \mathrm{Fe}^{2+} / \mathrm{l}$, respectively), 14 (1104, 1202 and $1287 \mathrm{nM}$ $\mathrm{Fe}^{2+} / \mathrm{l}$, respectively) and 21 (1122, 1309 and $1344 \mathrm{nM} \mathrm{Fe}^{2+} / \mathrm{l}$, respectively) there was a significant $(\mathrm{p}<0.05, \mathrm{p}<0.01$ and $\mathrm{p}<0.001)$ increase in ferric reducing ability of plasma (FRAP) value compared with day $0\left(869,870\right.$ and $871 \mathrm{nM} \mathrm{Fe}^{2+} / \mathrm{l}$, respectively). Similarly, in group V, VI and VII on days 7 (941, 1075 and $1095 \mathrm{nM}$ $\mathrm{Fe}^{2+} / \mathrm{l}$, respectively), 14 (1097, 1189 and $1265 \mathrm{nM} \mathrm{Fe}^{2+} / \mathrm{l}$ respectively) and $21\left(1103,1297\right.$ and $1321 \mathrm{nM} \mathrm{Fe}^{2+} / \mathrm{l}$, respectively) there was a significant $(p<0.05, p<0.01$ and $p<0.001)$ increase in ferric reducing ability of plasma (FRAP) value compared with day $0\left(868,870\right.$ and $871 \mathrm{nM} \mathrm{Fe}^{2+} / \mathrm{l}$, respectively). Maximum enrichment of ferric reducing ability of plasma (FRAP) level was found in group IV and VII, which correspond to animals administered with $500 \mathrm{mg} / \mathrm{kg}$ body weight of the methanol extract of Limnophila heterophylla and Michelia champaca, individually.

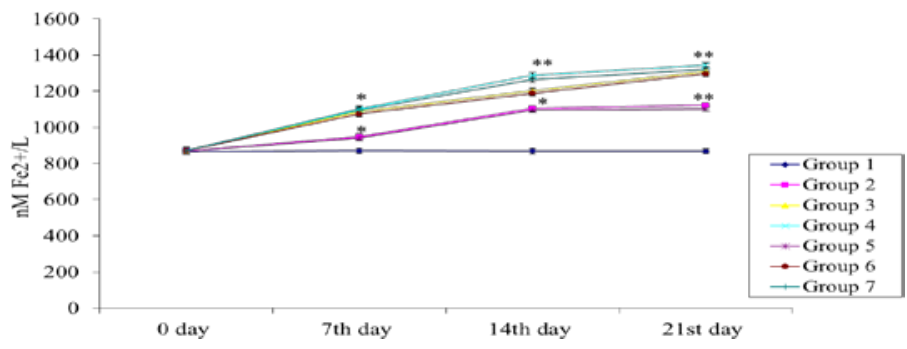

Fig. 1: Changes in rat total antioxidant capacity of the ferric reducing ability of plasma (FRAP) measured by $\mathrm{Fe}^{2+}$ equivalent after administration of methanol extract of Limnophila heterophylla and Michelia champaca. Values were mean \pm s. d (n=6). Group II, III, IV, V, VI and VII (Plant Extracts Treated Rats) Compared to Group I (control rats). p<0.05* and p $<0.01 * *$

\section{Estimation of superoxide dismutase (SOD)}

The treatment of methanol extract of both plants caused minor significant $(\mathrm{p}<0.05, \mathrm{p}<0.01$ and $\mathrm{p}<0.001)$ decrease at $125 \mathrm{mg} / \mathrm{kg}(510$ and 498 units $/ \mathrm{mg}$ of protein), $250 \mathrm{mg} / \mathrm{kg}$ (528 and $524 \mathrm{units} / \mathrm{mg}$ of protein) and $500 \mathrm{mg} / \mathrm{kg}$ (536 and 532 units/mg of protein) bodyweight in the level of superoxide dismutase (SOD) in the heart compared with the control (522 units/mg of protein). However, the level of superoxide dismutase (SOD) in the kidney and liver of the both plants treated rats was not dose related and was found to be significantly increased $(\mathrm{p}<0.05, \mathrm{p}<0.01$ and $\mathrm{p}<0.001)$ at the three different doses of $125 \mathrm{mg} / \mathrm{kg}$ (206, 198 and 428, 419 units/mg of protein, respectively), $250 \mathrm{mg} / \mathrm{kg}$ (218, 209 and 462, 455 units/mg of protein, respectively) and 500 $\mathrm{mg} / \mathrm{kg}(220,211$ and 478, 469 units/mg of protein, respectively) compared with the control (group-I) (204 and 424 units/mg of protein, respectively). The results were shown in fig. 2, 3 and 4 .

\section{Estimation of catalase (CAT)}

The administration of methanol extract of both plants to normal rats for $21 \mathrm{~d}$ induced a dose-dependent increase in the level of catalase (CAT) in liver (fig. 2) and kidney (fig. 4), but a decrease in the heart (fig. 3). Methanol extract of both plants were significantly increased at $500 \mathrm{mg} / \mathrm{kg}$ body weight dose of the treatment $(\mathrm{p}<0.001)$ for liver (344 and 339 units/mg of protein) and kidney (402 and 394 units/mg of protein) compared with the control group of liver and kidney (312 and 385 units/mg of protein, respectively). However, there was a little change in the endogenous antioxidant levels in heart tissue. Similarly, for both the plants at a dose of 125 and 250 $\mathrm{mg} / \mathrm{kg}$ a significant increase $(\mathrm{p}<0.05$ and $\mathrm{p}<0.01)$ in the catalase (CAT) levels were observed for liver (308 and 298 units/mg of protein) and kidney (387 and 374 units/mg of protein) compared with the control group.

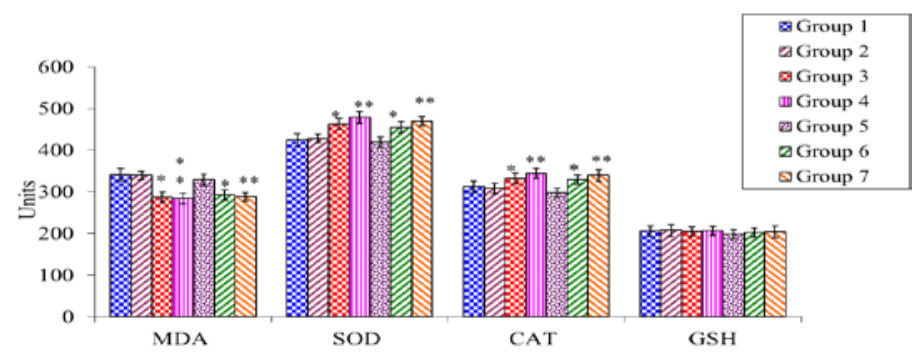

Fig. 2: Changes in rat liver thiobarbituric acid reactive substance (TBARS; nmol/g wet weight [wt]), superoxide dismutase (SOD; units/mg protein), catalase (CAT; units/mg protein) and reduced glutathione (GSH; $\mu \mathrm{g} / \mathrm{g}$ wet $\mathrm{wt}$ ) following oral administration of methanol extracts of Limnophila heterophylla and Michelia champaca. Values were mean $\pm \operatorname{SD}(\mathrm{n}=6)$. $\mathrm{p}<0.05^{*}$ and $\mathrm{p}<0.01^{* *}$, compared with control 


\section{Estimation of thiobarbituric acid reactive substance (TBARS)}

The effect of different doses of individual methanol extract of Limnophila heterophylla and Michelia champaca on the lipid peroxidation and endogenous antioxidants of liver, heart and kidney of rats was shown in fig. 2, 3 and 4 respectively. For groups II, III, and IV, a significant $(\mathrm{p}<0.05, \mathrm{p}<0.01$ and $\mathrm{p}<0.001)$ decrease in thiobarbituric acid reactive substance (TBARS) concentration in liver $(339,287$ and $284 \mathrm{~nm} / \mathrm{g}$ wet weight [wt] tissue, respectively) and kidney (182, 176 and $162 \mathrm{~nm} / \mathrm{g}$ wet wt tissue, respectively) was observed and compared with the control group (341 and $184 \mathrm{~nm} / \mathrm{g}$ wet wt tissue in liver and kidney, respectively). Similarly, for groups V, VI and VII a significant $(\mathrm{p}<0.05, \mathrm{p}<0.01$ and $\mathrm{p}<0.001)$ decrease in thiobarbituric acid reactive substance (TBARS) concentration in liver $(329,292$ and $288 \mathrm{~nm} / \mathrm{g}$ wet weight [wt] tissue, respectively) and kidney (176, 179 and $168 \mathrm{~nm} / \mathrm{g}$ wet wt tissue, respectively) was observed and compared with the control group (341 and $184 \mathrm{~nm} / \mathrm{g}$ wet wt tissue in liver and kidney, respectively). Also, the experiment study indicated that a negligible change in the level of thiobarbituric acid reactive substance (TBARS) in the heart was observed for all treated groups.

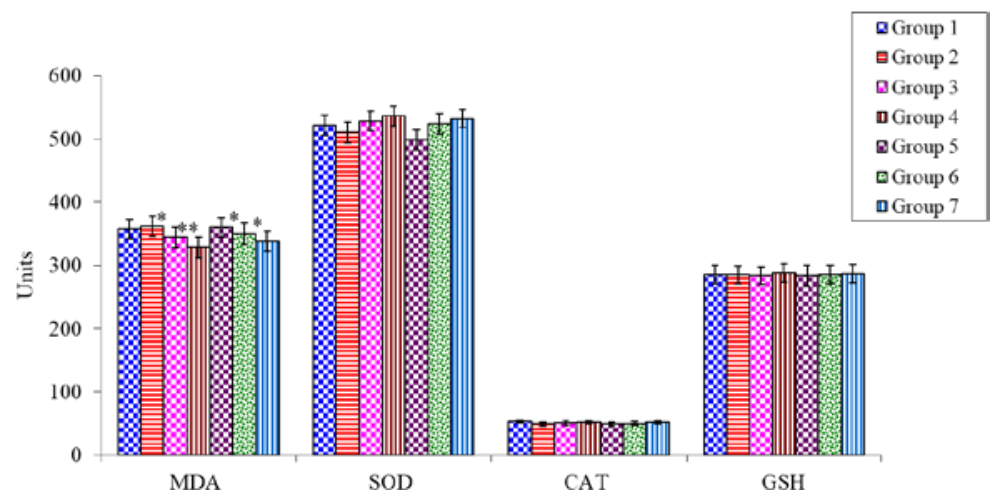

Fig. 3: Changes in rat heart thiobarbituric acid reactive substance (TBARS; nmol/g wet weight [wt]), superoxide dismutase (SOD; units/mg protein), Catalase (CAT; units/mg protein) and Reduced Glutathione (GSH; $\mu \mathrm{g} / \mathrm{g}$ wet wt) following oral administration of methanol extracts of Limnophila heterophylla and Michelia champaca, values were mean $\pm \mathrm{SD}(\mathrm{n}=6) . \mathrm{p}<0.05^{*}$, compared with control

\section{Estimation of reduced glutathione (GSH)}

For groups II, III and IV, there was no significant change of reduced glutathione (GSH) level in liver (207, 205 and $206 \mathrm{mg} / \mathrm{g}$ wet wt tissue, respectively), heart $(285,287$ and $284 \mu \mathrm{g} / \mathrm{g}$ wet wt tissue, respectively) and kidney $(91,87$ and $89 \mu \mathrm{g} / \mathrm{g}$ wet wt tissue, respectively) compared with the control group of liver (fig. 2), heart (fig. 3) and kidney (fig. 4) (206, 286 and $88 \mu \mathrm{g} / \mathrm{g}$ wet wt tissue, respectively). Similarly, the methanol extract of Michelia champaca showed no significant change in the level of reduced glutathione (GSH) in liver, heart and kidney at a dose of 125, 250 and $500 \mathrm{mg} / \mathrm{kg}$.

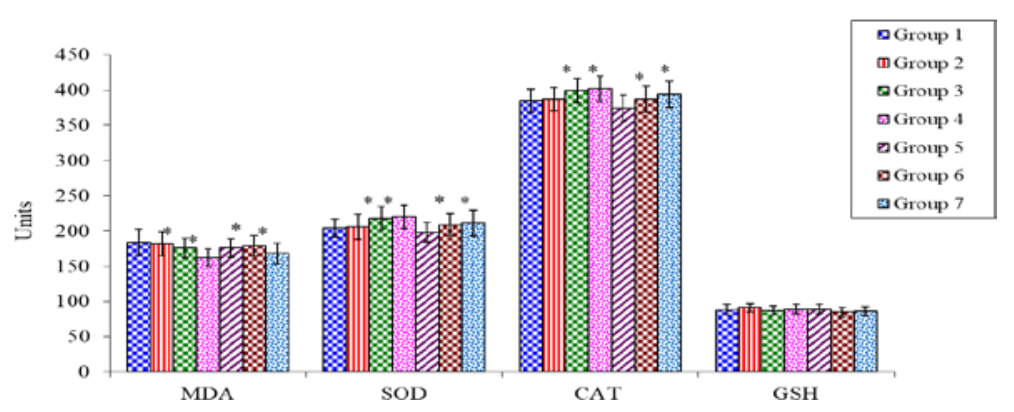

Fig. 4: Changes in rat kidney thiobarbituric acid reactive substance (TBARS; nmol/g wet weight [wt]), superoxide dismutase (SOD; units $/ \mathrm{mg}$ protein), catalase (CAT; units/mg protein) and reduced glutathione (GSH; $\mu \mathrm{g} / \mathrm{g}$ wet wt) following oral administration of methanol extracts of Limnophila heterophylla and Michelia champaca. values were mean \pm SD $(n=6)$. p<0.05*, compared with control

\section{DISCUSSION}

Excessive production of reactive oxygen species (ROS) plays a very important role within the pathologic process and progression of many diseases together with completely different organs [33]. The principle for the utilization of antioxidants is well established in interference and treatment of chronic diseases wherever aerobic stress plays a serious aetiopathological role. varied population studies support that consumption of natural sources of fruits and vegetables, rich in antioxidant compounds, are related to a lower incidence of aerobic stress evoked diseases [34].

In the present investigation, the ferric reducing ability of plasma (FRAP) test measured total antioxidant capacity determined by nonenzymatic antioxidants. Numerous approaches have been established to assess the total antioxidant capacity of plasma or serum because of the difficulty in measuring each antioxidant component separately in the serum or plasma [35]. One of these is the ferric reducing ability of plasma (FRAP), which measures the reduction of $\mathrm{Fe}^{3+}$ to $\mathrm{Fe}^{2+}$ in the presence of water-soluble exogenous antioxidants [28]. The significant increase in ferric reducing ability of plasma (FRAP) level after oral administration of methanol extract of both plants (Limnophila heterophylla and Michelia champaca) indicates the presence of bio-available antioxidants in these plants. As mentioned above, the maximum enhancement was obtained in group IV and VII after $21 \mathrm{~d}$ of handling. Also, ROS react with all biological substance; however, the most susceptible ones are polyunsaturated fatty acids. Reactions with these cell membrane constituents lead to lipid peroxidation (LPO) [36]. Increased LPO impairs membrane function by decreasing membrane fluidity and changing the activity of membrane-bound enzymes and receptor 
[37]. Thiobarbituric acid reactive substance (TBARS) levels were measured as a marker of LPO and malondialdehyde (MDA) production. Malondialdehyde is an endogenous genotoxic product of enzymatic and ROS-induced LPO whose adducts are known to exist in DNA isolated from healthy human being [38]. In our study, the level of thiobarbituric acid reactive substance (TBARS) in the extracts treated groups decreased in a dose-dependent manner when compared to control The present study showed the depletion in the lipid peroxidation as observed by significant decrease in the thiobarbituric acid reactive substance (TBARS) level of the liver and kidney in the plant extracts treated groups, but there was no change of thiobarbituric acid reactive substance (TBARS) level in heart as compared to control.

The superoxide dismutase (SOD) catalyzes the dismutation of superoxide to hydrogen peroxide and oxygen, thereby reducing the likelihood of superoxide anion reacting with nitric oxide to form reactive peroxynitrite [39]. It is an effective defence of the cell against the endogenous and exogenous generation of superoxide [40]. Catalase (CAT) is a ubiquitous enzyme that catalyzes the decomposition of hydrogen peroxide, a reactive oxygen species, which is a toxic product of both normal aerobic metabolism and pathogenic ROS production [41]. The ROS scavenging activity of superoxide dismutase (SOD) is effective only when it is followed by the action of catalase (CAT) and glutathione peroxidase (GPX), because of the dismutase activity of superoxide dismutase (SOD) generates hydrogen peroxide from the superoxide ion, which is more toxic than oxygen-derived free radicals and required to be scavenged further by catalase (CAT) and glutathione peroxidase (GPX) [42]. The administration of methanol extract of both plants at $500 \mathrm{mg} / \mathrm{kg}$ body weight significantly increased the level of superoxide dismutase (SOD) and catalase in liver and kidney.

This shows the antioxidant nature of both the extracts. Generally, results for the kidney have shown fewer changes in antioxidant activity compared to the liver [43]. However, decrease in the level of superoxide dismutase (SOD) and catalase (CAT) was observed in the heart, which could explain the present observation. Reduced glutathione is a protective molecule against chemical-induced cytotoxicity [44]. Glutathione is involved in many imperative cellular functions, ranging [43] from the control of physicochemical belongings of cellular proteins and peptides to the detoxification of free radicals [45]. However, longterm administration of the methanol extracts of two plants did not show significant results in reduced glutathione (GSH) levels of liver, heart and kidney indicating a protective antioxidant effect.

\section{CONCLUSION}

It can be concluded that the methanol extracts of Limnophila heterophylla and Michelia champaca had significant in vivo antioxidant activity. The antioxidant action of methanol extracts of both plants may be attributed to the presence of known bioactive compounds (flavonoids), which provides maximum conjugation with radical species, thus reducing the number of free radicals available as well as oxidative stress-related ailments (diabetes, Alzheimer's disease, atherosclerosis, arthritis, cancer) of major organs such as liver, kidney and heart.

\section{ACKNOWLEDGEMENT}

The authors are grateful to the University Grant Commission for providing financial assistance in the form of UGC-MRP fellowship to GITAM Institute of pharmacy, GITAM University, Visakhapatnam, Andhra Pradesh, India.

\section{AUTHORS CONTRIBUTION}

The complete research work was suggested and designed by Raja S. Extraction process and in vivo antioxidant activity was carried out by Ravindranadh K. The manuscript was drafted by Ravindranadh K. The manuscript was edited by Ravindranadh K. Authors read and approved the final manuscript.

\section{CONFLICT OF INTERESTS}

Declared none

\section{REFERENCES}

1. Maxwell SR. Prospects for the use of antioxidant therapies. Drugs 1995;49:345-61.

2. Kazim H, Stephen R, Hazelrig G. Oxidative injury due to chronic nitric oxide synthase inhibition in rat: effect of regular exercise on the heart. Biochim Biophys Acta Mol Basis Dis 2002;1587:75-82.

3. Jacob RA. The integrated antioxidant system. Nutr Res 1995;15:755-66.

4. Rice-Evans C, Halliwell B, Lunt GG. Free Radicals and Oxidative Stress: Environment, Drugs and Food additives. $2^{\text {nd }}$ edition. Portland press: London; 1995.

5. Aqil F, Ahmad I, Mehmood Z. Antioxidant and free radical scavenging properties of twelve traditionally used Indian medicinal plants. Turkish J Biol 2006;30:177-83.

6. Costantino L, Albasini A, Rastelli G, Benvenuti S. Activity of polyphenolic crude extracts as scavengers of superoxide radicals and inhibitors of xanthine oxidase. Planta Med 1992;5:342-4.

7. Mukherjee PK. Quality control of herbal drugs-an approach to the evaluation of botanicals, Business Horizons, New Delhi, India; 2002. p. 560-7.

8. Merfort I, Heilmann J, Weis M, Pietta P, Gardana C. Radical scavenger activity of three flavonoid metabolites studied by inhibition of chemiluminescence in human PMNs. Planta Med 1996;62:289-92.

9. Arul Manikandan PN. Folk herbal medicine: a survey on the paniya tribes of the mundakunnu village of the Nilgiri Hills, South India. Anc Sci Life 2005;25:21-7.

10. Brahmachari G, Jash SK, Mandal LC, Mondal A, Roy R Cyclooxygenase (COX)-Inhibitory Flavonoid from Limnophila heterophylla. Rasayan J Chem 2008;1:288-91.

11. Padiya RH, Patel ED, Acharya RN. Evaluation of antimicrobial activity of Limnophila heterophylla (Roxb.) benth. (Scrophulariaceae) whole plant. Int J Ayur Med 2013;4:27-3.

12. Reddy GBS, Melkhani AB, Kalyani GA, Rao JV, Shirwaikar A, Kotian $\mathrm{M}$, et al. Chemical and pharmacological investigations of Limnophila conferta and Limnophila heterophylla. Int J Pharmacog 1991;29:145-53.

13. Rastogi RP, Mehrotra BN. Compendium of Indian Medicinal Plants. Eds. CDRI and NISCOM, New Delhi, India; 1998;4:435.

14. Gupta S, Mehla K, Chauhan D, Nair A. Anti-inflammatory activity of leaves of Michelia champaca investigated on acute inflammation induced rats. Latt Am J Pharm 2011;30:819-22.

15. Hoffmann JJ, Torrance SJ, Wiedhopf RM, Cole JR. Cytotoxic agents from Michelia champaca and Talauma ovata: Parthenolide and Costunolide. J Pharm Sci 1977;66:883-4.

16. Vimala R, Nagarajan S, Alam M, Susan T, Joy S. Anti-inflammatory and antipyretic activity of Michelia champaca Linn., (white variety), Ixora brachiata Roxb, and Rhynchosia cana (Willd.) DC flower extract. Indian J Exp Biol 1997;35:1310-4.

17. Jarald EE, Joshi SB, Jain DC. Antidiabetic activity of flower buds of Michelia champaca Linn, Indian J Pharmacol 2008;40:256.

18. Takahashi M, Fuchino H, Satake M, Agatsuma Y, Sekita S. In vitro screening of leishmanicidal activity in myanmar timber extracts. Biol Pharm Bull 2004;27:921-5.

19. Parimi U, Kolli D. Antibacterial and free radical scavenging activity of Michelia champaca Linn. Flower extracts. Free Radicals Antioxid 2012;2:58-61.

20. Shanbhag T, Kodidela S, Shenoy S, Amuthan A, Kurra S. Effect of Michelia champaca linn flowers on burn wound healing in wistar rats. Int J Pharm Sci Rev Res 2011;7:112-5.

21. Ahamad H, Mishra A, Gupta R, Saraf SA. Determination of gallic acid in Michelia champaca Linn. (champa) leaves and stem bark by HPTL. Pharm Lett 2011;3:307-17.

22. Mullaicharam AR, Kumar MS. Effect of Michelia champaca linn on pylorous ligated rats. J Appl Pharm Sci 2011;1:60-4.

23. Taprial S, Kashyap D, Mehta V, Kumar S, Kumar D. Antifertility effect of hydroalcoholic leaves extract of Michelia champaca L.: An ethnomedicine used by Bhatra women in the Chhattisgarh state of India. J Ethnopharmacol 2013;147:671-5.

24. Dama G, Bidkar J, Deore S, Jori M, Joshi P. Helmintholytic activity of the methanolic and aqueous extracts of leaves of Michelia champaca. Res J Pharmacol Pharmacodyn 2011;3:25-6. 
25. Rajshree S, Ranjana V, Michelia champaca L. (Swarna champa) a review. Int J Enhanc Res Sci Tech Eng 2016;5:78-82.

26. Rajlakshmi D, Banerjee SK, Sood S, Maulik SK. In vitro and in vivo antioxidant activity of different extracts of the leaves of Clerodendron colebrookianum Walp in the rat. J Pharm Pharmacol 2003;55:1681-6.

27. Yesufu HB, Bassi PU, Khaz IZ, Abdulrahaman FI, Mohammed GT. Phytochemical screening and hepatoprotective properties of aqueous root bark extract of Sarcocephalus latifolius (smith) bruce (African peach). Arch Clin Microbiol 2010;1:1-5.

28. Benzie IFF, Strain JJ. The ferric reducing ability of plasma (FRAP) as a measure of 'antioxidant power' the FRAP assay. Anal Biochem 1996;23:70-6.

29. Rai S, Wahile A, Mukherjee K, Saha BP, Mukherjee PK. Antioxidant activity of Nelumbo nucifera (sacred lotus) seeds. J Ethnopharmacol 2006;104:322-7.

30. Aebi H. Catalase in vitro. Methods Enzymol 1984;10:121-6.

31. Liu J, Edamatsu R, Kabuto H, Mori A. Antioxidant action of guilingji in the brain of rats with $\mathrm{FeCl}_{3}$-induced epilepsy. Free Radical Biol Med 1990;9:451-4.

32. Ellman GL. Tissue sulfhydryl groups. Arch Biochem Biophys 1959;82:70-7.

33. Visioli F, Keaney JF, Halliwell B. Antioxidant and cardiovascular disease; panacea or tonics for tired sheep. Cardiovascular Res 2000;47:409.

34. Vayalil PK. Antioxidant and antimutagenic properties of aqueous extract of date fruit (Phoenix dactylifera L, Arecaceae). J Agric Food Chem 2002;50:610-7.
35. Cao G, Prior RL. Comparison of different analytical methods for assessing the total antioxidant capacity of human serum. Clin Chem 1998;4:1309-15.

36. Bakirel T, Bakirel U, Keles OU, Ulgen SG, Yardibi H. In vivo assessment of antidiabetic and antioxidant activities of rosemary (Rosmarinus officinalis) in alloxan-diabetic rabbits. J Ethnopharmacol 2008;116:64-73.

37. Arulselvan P, Subramanian SP. Beneficial effects of Murraya koenigii leaves on antioxidant defense system and ultrastructural changes of pancreatic ß-cells in experimental diabetes in rats. Chem Biol Interact 2007;165:155-64.

38. Niedernhofer LJ, Daniels JS, Rouzer CA, Greene RE, Marnett LJ. Malondialdehyde, a product of lipid peroxidation is mutagenic in human cells. J Biol Chem 2003;278:31426-33.

39. Maritim AC, Sanders RA, Watkins JB. Diabetes, oxidative stress and antioxidants: a review. J Biochem Mol Toxicol 2003;17:24-38.

40. Brawn K, Fridovich I. Superoxide radical and superoxide dismutase threat and defense. Acta Physiol Scand Suppl 1980;49:9-18.

41. Kohen R, Nyska A. Oxidation of biological systems: oxidative stress phenomena, antioxidants, redox reactions, and methods for their quantification. Toxicol Pathol 2002;30:620-50.

42. Blake DR, Allen RE, Lunee J. Free radicals in biological systems: a review oriented to the inflammatory process. Br Med Bull 1987;4:371-85.

43. Jadwiga JL, Marek M, Elzbeita B. Effect of sesquiterpene lactones on antioxidant enzymes and some drug metabolizing enzymes in rat liver and kidney. Planta Med 2000;66:199-205.

44. Orrenius S, Moldeus P. The multiple roles of glutathione in drug metabolism. Trends Pharmacol Sci 1984;5:432.

45. Meister A, Anderson ME. Glutathione. Annu Rev Biochem 1983;52:711-60. 